\title{
Early post-settlement mortality of an intertidal barnacle: a critical period for survival
}

\author{
Louis A. Gosselin ${ }^{1, *}$, Pei-Yuan Qian ${ }^{2}$ \\ ${ }^{1}$ Department of Biological Sciences, University of Alberta, Edmonton, Alberta, Canada T6G 2E9 \\ ${ }^{2}$ Department of Biology, Hong Kong University of Science and Technology, Clear Water Bay, Kowloon, Hong Kong
}

\begin{abstract}
To determine if the onset of intertidal life is a critical time for survival, we examined the fate of newly settled Balanus glandula, an intertidal barnacle, on natural rocky substrata in Barkley Sound, British Columbia, Canada. In total, 552 individual settlers were mapped and followed daily during their first 3 to $5 \mathrm{~d}$ after settlement in May 1992 and were then periodically re-examined over a $45 \mathrm{~d}$ period. A sharp decline in survivorship occurred during the first day after settlement. For settlers arriving on 16 and 17 May, mortality during the first day after settlement (38.0\%) was almost as high as all mortality during the following $44 \mathrm{~d}(40.1 \%)$. Mortality during the first day after settlement was 1.5 to 6.0 times higher than during the second day for settlers arriving on 16, 17 and 18 May. There was no relationship, however, between percent first day mortality and densities of recruits or of grazers (limpets, littorines). The elevated levels of first day mortality were also not consistent with desiccation stress, wave exposure, or size-specific changes in vulnerability. The first moments after settlement may constitute a bottleneck for the survival of barnacles settling in the intertidal zone. For organisms such as B. glandula, selective pressures for traits such as time of settlement relative to the tidal cycle, selection of settlement micro-site, and energy reserves at settlement could be most intense during the first day in the benthic habitat.
\end{abstract}

KEY WORDS: Bottleneck - Bulldozing - Early juvenile - Density-dependent mortality Recruitment Sessile invertebrates Settlement Survivorship

\section{INTRODUCTION}

Benthic marine invertebrates are generally most vulnerable during the early juvenile period to factors such as desiccation, temperature stress, mechanical damage, and predation (Foster 1971, Connell 1972, Branch 1975. Denley \& Underwood 1979, Underwood 1979, Gosselin \& Chia 1995). Although mortality factors may change during ontogeny, overall vulnerability generally decreases as the juvenile increases in size (Vermeij 1972, Werner \& Gilliam 1984). This will produce a corresponding age-specific mortality pattern, mortality decreasing with increasing age (Frank 1965, Feare 1970). Consequently, mortality during the early juvenile period is often high (Connell 1961, Thorson 1966,

\footnotetext{
- Present address: Department of Biology, Hong Kong University of Science and Technology, Clear Water Bay, Kowloon, Hong Kong. E-mail: lgosseli@usthk.ust.hk
}

Branch 1975) and has been shown to be important in determining the abundance and distribution of ascidians (Osman et al. 1992, Osman \& Whitlatch 1995), barnacles (Connell 1961. Denley \& Underwood 1979), hydroids (Yund et al. 1987), limpets (Branch 1975), polychaetes (Qian \& Chia 1994) and urchins (Rowley 1989). In species with planktonic larvae, young individuals also face 2 considerable challenges during and immediately after settlement: they must undergo metamorphosis, which may involve extensive changes in anatomy, physiology and metabolism (e.g. see Chia \& Burke 1978), and the transition from pelagic to benthic habitats exposes them to an entirely different set of environmental conditions within a very short period of time. This is especially true of intertidal organisms, which first experience emersion within hours after settlement. The brief period at the onset of benthic life could thus be a critical time for survival (Keough \& Downes 1982). 
Existing information on barnacles sheds some light on the magnitude of mortality during the first day after settlement. In a study of Semibalanus balanoides, Connell (1961, Fig 5 therein) reported that -10 to $45 \%$ of new settlers on intertidal stones died as cyprids. Later, Young (1991) observed that 53 to $78 \%$ of Chthamalus fragilis settling on Spartina alterniflora died during the first day after settlement. These results suggest that mortality during an initial period after settlement might be higher than has generally been considered. However, daily mortality rates for subsequent days were not reported in these studies and the hypothesis of early post-settlement as a critical period was not considered. Indeed, the fate of individual settlers in the intertidal has seldom been reported for consecutive intervals on a time scale short enough to verify the existence of an initial critical period.

The assessment of survivorship over brief intervals for the first few days of benthic life can help determine if selective processes in the intertidal zone are more intense at the onset of benthic life and, if so, how long this critical period lasts. Such information can also be of direct significance for studies of recruitment, as it can help in the planning of future studies by identifying intervals that provide the best compromise between minimizing observation frequency and maximizing the accuracy of settlement and mortality data.

The objectives of this study were to: (1) document age-specific mortality of newly settled Balanus glandula Darwin on a daily basis in the field. This would in turn serve to determine if the transition to the benthic habitat corresponds to a distinct period of high initial mortality and, if so, how long this period lasts; and (2) examine recruit density and size-specific mortality in the field to evaluate their importance as sources of early post-settlement mortality.

\section{MATERIALS AND METHODS}

Study sites. Field work was conducted in Barkley Sound on the west coast of Vancouver Island, British Columbia, Canada, from 15 May to 29 June 1992. Two sites at Kirby Point on Diana Island were selected: an exposed site $\left(48^{\circ} 50^{\prime} 85^{\prime \prime} \mathrm{N}, 125^{\circ} 12^{\prime} 40^{\prime \prime} \mathrm{W}\right.$; orientation: $\left.215^{\circ}\right)$, directly exposed to ocean surf, and a protected site $\left(48^{\circ} 50^{\prime} 80^{\prime \prime} \mathrm{N}, 125^{\circ} 12^{\prime} 25^{\prime \prime} \mathrm{W}_{\text {; }}\right.$ orientation: $\left.55^{\circ}\right)$, facing away from incoming waves, located in a small sheltered bay approximately $300 \mathrm{~m}$ from the exposed site. Macroalgae were absent from all transect areas except in the low area of the protected site, where some tufts of Fucus spp. were present. Both sites were exposed to direct sunlight during daytime low tide periods. Weather throughout the first $7 \mathrm{~d}$ of the study and most of the following $39 \mathrm{~d}$ was sunny. The highest daytime air temperatures recorded in Grappler Inlet $\left(48^{\circ} 50^{\prime} 05^{\prime \prime} \mathrm{N}, 125^{\circ} 06^{\prime} 90^{\prime \prime} \mathrm{W}\right), 6.4 \mathrm{~km}$ from Kirby Point, were $28^{\circ} \mathrm{C}$ in May and $27^{\circ} \mathrm{C}$ in June, maximum temperatures in the intertidal, however, were usually 4 to $8^{\circ} \mathrm{C}$ cooler than in Grappler Inlet (Gosselin \& Chia 1995). During the study, wave conditions were moderate and surface water temperature ranged from 13 to $15^{\circ} \mathrm{C}$.

Age-specific post-settlement mortality. To determine if the onset of benthic life is associated with particularly high mortality rates, the fate of individual newly settled Balanus glandula was monitored along 3 horizontal $6 \mathrm{~m}$ transects, designated herein as 'high', 'mid', and 'low', established at each site on 5 May 1992. High, mid, and low transects at the exposed site were established at 4.5, 3.6, and $2.0 \mathrm{~m}$ above mean lower low water (MLLW), and equivalent transects at the protected site were respectively 4.3,3.6, and $2.6 \mathrm{~m}$ above MLLW. Tidepools were avoided as they would have affected desiccation gradients associated with intertidal height. Twenty-four quadrats $(4 \times 4 \mathrm{~cm})$ were positioned at $25 \mathrm{~cm}$ intervals along the transects. The exact location of each quadrat on the rock surface was established by marking the position of the 2 lower quadrat corners with nail polish.

Barnacle settlement, mortality, and recruitment have previously been examined in the field using photographic (Wethey 1984, Caffey 1985, Gaines et al. 1985), marking (Young 1991), and mapping (Connell 1961, Raimondi 1990, Young 1991) techniques or by directly counting settlers (Qian \& Liu 1990, Minchinton \& Scheibling 1993). Although mapping is time consuming, we chose this method because it was the most reliable way of monitoring the fate of each newly settled barnacle, including many that were hidden by surface irregularities. Consequently, the settlement and subsequent fate of each Balanus glandula settling within the quadrats was determined by locating each new settler with a magnifying lens and then mapping its position on a clear plastic sheet using waterproof marking pens. The position of every cyprid and metamorphosed $B$. glandula found within the 144 quadrats (24 quadrats $\times 3$ tidal heights $\times 2$ sites) was mapped daily from 15 May (Day 0) to 21 May (Day 6). Observations were then repeated on 30 May (Day 15) and 29 June (Day 45) 1992. Missing individuals were recorded as deaths (see 'Discussion' for comments regarding the implications of this approach). Most dead settlers were either missing, were found as empty shells, or had gaping valves and did not respond when touched. The careful removal of dead individuals after each inspection and the initial application of 2 spots of nail polish to mark the position of each quadrat were the only alterations made to the habitat throughout this study. Over the initial period of daily observations the tides 
reached their lowest from 06:22 h (15 May) to 10:27 h (21 May); thus, when daily mortality rates were determined, the intertidal was submerged during the warmest part of the day.

Mortality was calculated in 2 ways (see equations in Table 1). Cohort mortality was based on the ratio of deaths during a given interval to initial cohort size; it thus indicates the importance of an age interval in terms of overall effect on the cohort. Interval mortality was based on the ratio of deaths during a given time interval to the number of individuals at the start of that interval; it is an instantaneous rate of mortality, indicating the proportional rate at which the cohort decreased during that interval.

Effect of recruit density. To examine the relationship between early post-settlement mortality and recruit density, regression analysis was carried out between the number of recruits present in each quadrat and the percentage of new settlers dying during their first day in the intertidal zone. Recruits (live individuals that had settled during the current settlement season, including those that settled during our study) could easily be distinguished from adults based on the small size and smoother, whiter shell of the recruits. To provide meaningful values of percentage mortality, only quadrats receiving at least 4 new settlers between 16 and 18 May were included in the analysis.

Size-specific post-settlement mortality. To examine whether the age-specific mortality pattern corresponds to size-specific changes in vulnerability, we examined the fate of recruits with opercular diameter sizes falling within 4 classes (class 1: 0.5 to $0.6 \mathrm{~mm}$; class $2: 0.8$ to

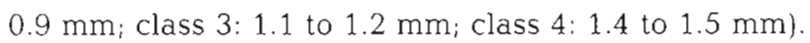
The size ranges used as classes were determined by collecting nearby rocks supporting Balanus glandula recruits and measuring individuals of a range of sizes using a dissecting microscope. Barnacles of the chosen size classes were clearly discernible, and therefore

Table 1 Balanus glandula. Daily post-settlement mortality rates of 387 barnacles. Pooled results of all individuals that settled in the exposed and protected transects on 16 and 17 May. Mortality rates are calculated as follows (modified from Krebs 1985):

(A) $\%$ cohort mortality $($ per day $)=\left\{1-\left(1-D / C_{0}\right)^{1 / t}\right\} \times 100$

(B) $\%$ interval mortality $($ per day $\left.)=\mid 1-\left(1-D_{/ N}\right)^{1 / 4}\right\} \times 100$

where $C_{0}$ is initial cohort size (here $C_{0}=387$ ), $N_{1}$ is number of individuals at start of a given interval, $D$ is number of deaths during the interval, and $t$ is number of days in interval

Age interval (days after settlement)

0-1 $\quad 1-2 \quad 2-3 \quad 3-4 \quad 4-15 \quad 15-45$

$\begin{array}{lllllll}\text { (A) Cohort mortality } & 38.0 & 7.2 & 3.9 & 4.4 & 1.6 & 0.3\end{array}$

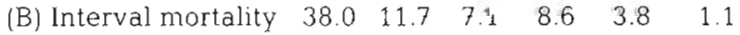

selected barnacles in the transect quadrats were visually allocated to size classes. Size class 1 included the smallest individuals present. Ten quadrats $(4 \times 4 \mathrm{~cm})$ were established at $25 \mathrm{~cm}$ intervals along a horizontal transect in the mid-intertidal zone at both sites. These transects were within $3 \mathrm{~m}$ of, and at the same height as, the mid-intertidal zone transects described in the agespecific mortality section. Barnacles were mapped according to size on a transparency sheet on 2 June 1992. The fate of these individuals was then determined 10 d later on 12 June

\section{RESULTS}

\section{Age-specific post-settlement mortality}

A total of 552 Balanus glandula cyprids settled in 5 transects on 16, 17 and 18 May 1992. No settlement was recorded in the exposed-low transect during that period, and only 8 new settlers were observed in this transect during the entire study. Consequently, no post-settlement mortality data was obtained from this transect.

Trends in age-specific survivorship were generally similar for all 5 transects (Fig. 1). A sharp decline in survivorship occurred during the first day after settlement, with the exception of the small 17 and 18 May cohorts in the exposed-mid and protected-high transects. The difference between first and second day mortality was not the result of an intense, short-term bout of unfavourable conditions; mortality during the first day after settlement was 1.5 to 6.0 times higher than during the second day after settlement for each of the 3 daily cohorts (Fig 2). This difference was significant $(t=6.20, p<0.025, n=3$, percentages arcsine transformed; Sokal \& Rohlf 1981) based on a 1-tailed paired $t$-test of interval mortality (Table 1, Eq. B) using each of the 3 daily cohorts as replicates. The difference in mortality rates between the first day of benthic life and subsequent days remained large whether mortality was calculated as a proportion of the initial number of new settlers (cohort mortality, Table 1, Eq. A) or as interval mortality (Table 1, Eq. B).

\section{Effect of recruit density}

Mortality of Balanus glandula during their first day after settlement was not related to recruit density. No significant relationship was detected in protected-high $(p=0.89, n=6)$, protected-mid ( $p=0.56, n=23)$, protected-low $(p=0.53, n=20)$, or exposed-high $(p=0.70$ $\mathrm{n}=12$ ) transects. In the quadrats used in this analysis recruit density ranged from 4 to 37 per quadrat $(4 \times$ 

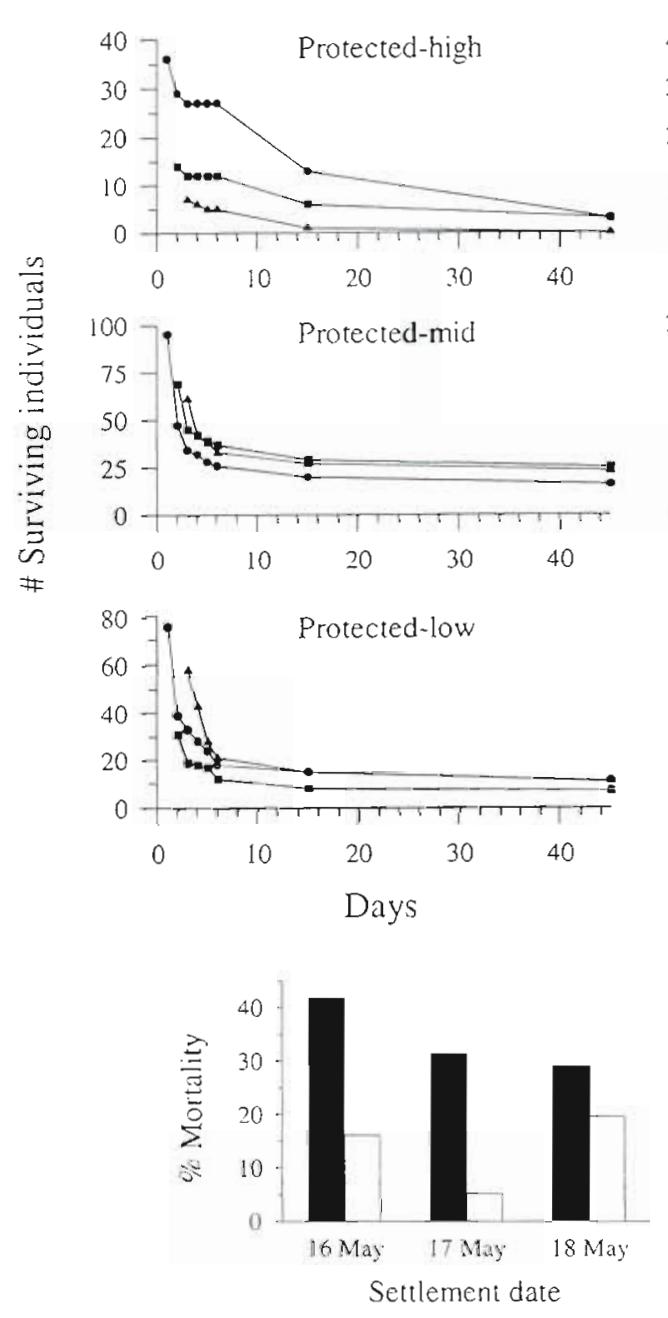

$$
\text { Firs! day } \square \text { Second day }
$$

Fig. 2. Balanus glandula. Interval mortality rate (see Table 1 , Eq. B) of newly settled barnacles during the first and second day after settlement. These results were obtained from all individuals settling on $16 \mathrm{May}(\mathrm{n}=246), 17$ May $(\mathrm{n}=140)$, and 18 May $1992(n=165)$

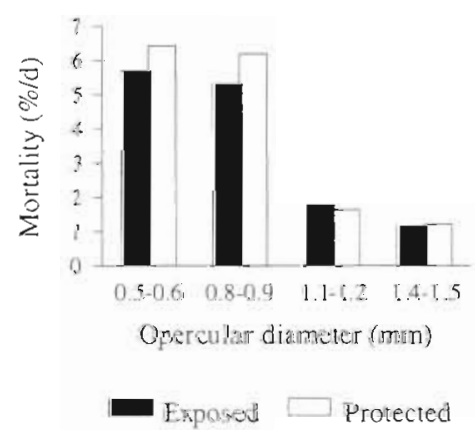

Fig. 3. Balanus glandula. Interval mortality rate (see Table 1 , Eq. B) of recruits in 4 opercular diameter size-classes from exposed and protected mid-intertidal transects. Initial numbers of live recruits ranged from 27 to 48
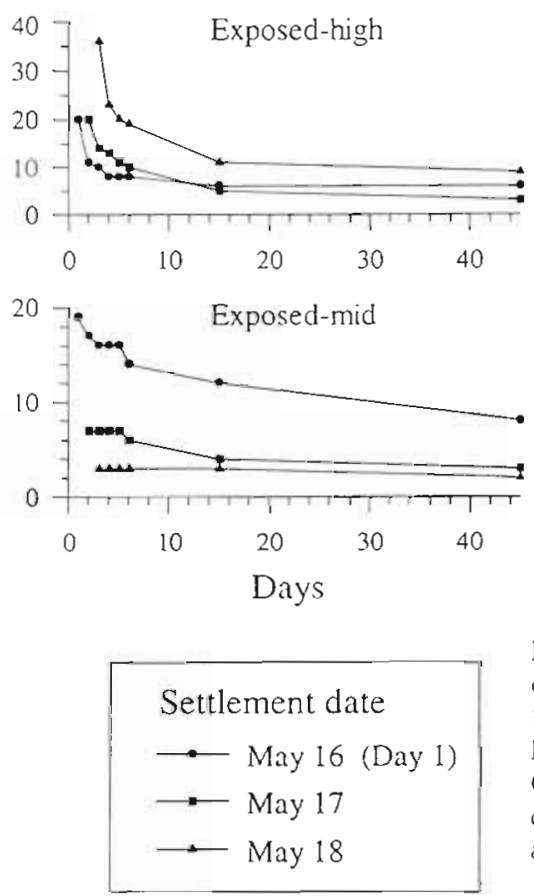

Fig. 1 Balanus glandula. Survivorship of 552 barnacles settling on 16, 17, and 18 May 1992 in intertidal transects at 2 Kirby Point sites (British Columbia, Canada). Individuals were monitored daily after settlement up to 21 May, and were then re-examined on 30 May

(Day 15) and 29 June (Day 45)

$4 \mathrm{~cm}$ ), and percentage of first day mortality ranged from 0 to 100 . Too few quadrats in the exposed-mid $(\mathrm{n}=2)$ and exposed-low $(\mathrm{n}=0)$ transects received enough new settlers to allow for regression analysis (see 'Materials and methods: Effect of recruit density'). When all transects were pooled in a single analysis the outcome was also non-significant ( $p=0.57, n=63)$. No non-linear relationship was apparent upon visual inspection of the plotted data.

\section{Size-specific post-settlement mortality}

Size-specific mortality over the $10 \mathrm{~d}$ period, calculated using Eq. (B) of Table 1 (interval mortality), was $-6 \% \mathrm{~d}^{-1}$ among the smallest size classes and decreased to $-1.2 \% \mathrm{~d}^{-1}$ among recruits in the largest size class (Fig. 3). Mortality rates of recruits of a given size class were not significantly different between exposed and protected sites (tests of independence, $G$ values adjusted using William's correction; Sokal \& Rohlf 1981: class 1: $G_{\text {adj }}=0.098, \mathrm{p}>0.70, \mathrm{n}=60 ;$ class $2: G_{\mathrm{adj}}$ $=0.157, \mathrm{p}>0.60, \mathrm{n}=74 ;$ class $3: G_{\partial \mathrm{djj}}=0.039, \mathrm{p}>0.80$, $\mathrm{n}=94 ;$ class $4: G_{\mathrm{ad}}=0.057, \mathrm{p}>0.80, \mathrm{n}=80$ ).

\section{DISCUSSION}

\section{Age-specific post-settlement mortality}

A substantial proportion of settlers successful in overcoming the odds against surviving through the lar- 


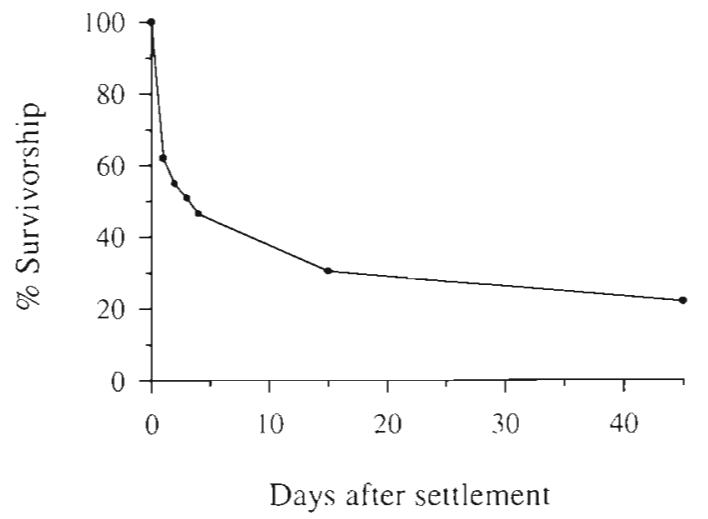

Fig. 4. Balanus glandula. Survivorship of 387 barnacles settling on 16 and 17 May 1992 (pooled results from all transects)

val stage (see Thorson 1950, Rumrill 1990) were unable to survive the transition to the benthic habitat. During the first $4 \mathrm{~d}$ after settling in the intertidal zone, $53.7 \%$ of the 16 and 17 May cohorts died. Wethey (1984) obtained similar results for Semibalanus balanoides: total mortality for individuals settling in and out of cracks was $54.1 \%$ and $51.2 \%$, respectively, during the first $6 \mathrm{~d}$ after settlement. In fact, a large proportion of newly settled $S$. balanoides (Connell 1961), Chthamalus fragilis (Young 1991), and Balanus glandula (present study) die during the first 1 to $1.5 \mathrm{~d}$ after settlement. Our results for $B$. glandula during the first days after settlement, as summarized in Fig, 4, suggest these intense levels of mortality are restricted to a brief period after settlement, possibly shorter than one day. Mortality during the following few days is high, but much less so than for the first day. For the 16 and 17 May cohorts, mortality during the first day after settlement $(147$ deaths $=38.0 \%)$ was almost as high as that during all of the following period up to Day 45 (155 deaths $=40.1 \%$ ). A distinct critical period of very short duration therefore does seem to occur and may constitute a bottleneck in populations of B. glandula and other barnacle species settling in the intertidal zone.

Detachment of settled cyprids and reattachment elsewhere are unlikely since the antennules by which initial attachment is effected would be encased in a mass of dried cement (Connell 1961). In addition, many deaths were recorded in calcified or partly calcified settlers, and at least some of the missing cyprids can be expected to have died. Thus, actual first day mortality was undoubtedly well in excess of that occurring during the second day. It is interesting to note, however, that first day mortality varied between transects and days, and was very low or nil for 2 daily cohorts at 2 sites (Fig. 1), indicating that first day mortality may contribute to recruitment variation over temporal and spatial scales.
When larvae of benthic marine invertebrates settle on intertidal substrata, they begin a radically different way of life. Several structural and behavioral traits that were useful to them as larvae (e.g. swimming appendages, ciliated feeding structures, and vertical migration behaviour) will be useless to them as juveniles; certain structures will in fact be discarded at metamorphosis. After surviving through the larval stage, settling individuals will largely depend on a different set of traits to survive as benthic juveniles. The high mortality observed during the first day after settlement suggests that the cost of mistakes, delays or other problems during the transition to benthic life will often be paid within hours after settlement.

When settlement and early post-settlement mortality of Balanus glandula are compounded (Table 2), it becomes clear that settlement and mortality could have been underestimated by at least 20 to $40 \%$ if our intervals between observations had been longer than 1 d. These results are in agreement with those of Minchinton \& Scheibling (1993) in which estimates of recruitment of Semibalanus balanoides using $2.1 \mathrm{~d}$ sampling intervals were $23 \%$ lower than estimates from $1.3 \mathrm{~d}$ intervals. As some cyprids undoubtedly settled, died, and disappeared even within the $1 \mathrm{~d}$ intervals used in this study, actual first day mortality was probably even higher than is reported here. Accurate evaluations of both settlement and early post-settlement mortality are necessary, regardless of whether mortality is density-dependent, to quantify the mechanisms controlling juvenile and adult abundance at a given site and to correctly evaluate the relative importance of pre-settlement and post-settlement processes.

Most motile benthic species are probably at least as vulnerable as sessile species during the early juvenile period. Indeed, Branch (1975) observed extensive mortality of limpets within $2 \mathrm{~d}$ of settlement and attributed this to desiccation, and newly hatched Nucella emar-

Table 2. Balanus glandula. Percentage of newly settled barnacles that would be found alive at the time of inspection as a function of time since the previous observation, ranging from 1 to $5 \mathrm{~d}$. The model compounds settlement, set at a fixed rate of 100 new settlers per day, and mortality, using the daily rates observed in the field during this study (see Table 1. Eq. A)

\begin{tabular}{|c|c|c|c|c|c|}
\hline & \multicolumn{5}{|c|}{ Observation interval (days) } \\
\hline & 1 & 2 & 3 & 4 & 5 \\
\hline $\begin{array}{l}\text { Cumulative total } \\
\text { no. of new settlers }\end{array}$ & 100 & 200 & 300 & 400 & 500 \\
\hline $\begin{array}{l}\text { No. of remaining } \\
\text { live settlers }\end{array}$ & 100 & 161 & 215 & 265 & 311 \\
\hline $\begin{array}{l}\text { Percentage of } \\
\text { settlers still alive }\end{array}$ & $100 \%$ & $80.5 \%$ & $71.7 \%$ & $66.3 \%$ & $62.2 \%$ \\
\hline
\end{tabular}


ginata, an intertidal snail, are extremely vulnerable to desiccation and predation (Gosselin \& Chia 1995). Patterns of age-specific mortality rates of motile early juveniles may nevertheless differ from those of sessile organisms. Motile early juveniles may seek protective habitats while still very small and thereby considerably reduce their likelihood of dying at the onset of benthic life. This strategy may provide sufficient benefits to explain why certain species that are essentially sessile as adults, such as mussels, retain a motile early juvenile stage that is initially distributed within structurally complex habitats until it reaches a larger size (e.g. see Bayne 1964, Petersen 1984).

\section{Effects of recruit density and body size}

First day mortality was not related to recruit density Recruit densities were relatively low, the highest recorded density being 2.3 recruits $\mathrm{cm}^{-2}$. Most new settlers were not in contact with other recruits or adults, and all quadrats had some free space throughout the study. In a review of barnacle recruitment studies, Connell (1985) found overall post-recruitment mortality to be density-independent at recruit densities ranging from 0.1 to 25 recruits $\mathrm{cm}^{-2}$. First day mortality of Balanus glandula may be influenced by recruit density in circumstances where recruitment is high, but the present results suggest first day mortality is density-independent at densities $\leq 2.3$ recruits $\mathrm{cm}^{-2}$.

For early post-settlement mortality to be proportional to size-specific vulnerability, a substantial increase in body size should have occurred between the first and second day after settlement, followed by sharply reduced growth during the following days. Although size increments were not recorded, we noticed no such change in size during the first $2 \mathrm{~d}$ after settlement. Also, Connell (1961) noted that newly settled Semibalanus balanoides actually decreased in size during metamorphosis, a process that occurred during the first $1.5 \mathrm{~d}$ after settlement. Mortality rates of $\mathrm{Bal}$ anus glandula during the first day after settlement were therefore not consistent with size-related vulnerability. Mortality rates of settlers aged 2 to $45 \mathrm{~d}$ (Table 1), however, were similar to those observed over the range of juvenile sizes that were studied (Fig 3), suggesting that changes in mortality during this later period may correspond to size-related changes in vulnerability.

\section{Desiccation, grazers, and other factors}

Early juvenile benthic invertebrates can be highly vulnerable to desiccation (Foster 1971, Gosselin \& Chia
1995), and this factor has been suggested as a major cause of juvenile mortality (Branch 1975, Denley \& Underwood 1979). Although the absence of settlement in the exposed-low transect precluded a full analysis of the effects of desiccation, first day mortality in our protected-low transect $(37.6 \%)$ was not lower than in the protected-mid $(36.6 \%)$ or protected-high transects $(11.27 \%)$, suggesting first day mortality was not proportional to desiccation stress

Percentage mortality during the first day after settlement was not significantly correlated (correlations: $0.36<p<0.63, n=5$ transects for each grazer species) with average densities of either of the most abundant grazer species (limpets: Lottia pelta and L. digitalis; littorines: Littorina scutulata, and combined counts of $L$. sitkana and Littorina sp. as described by Boulding et al. 1993) or with pooled densities of all grazers ( $p=$ $0.31, n=5$ ). Grazer densities were assessed 2 wk after the observations of first day barnacle mortality, but these grazers tend to be closely associated with specific shore levels (Kozloff 1983, authors' pers. obs.) and range of movements over periods of months can be limited to a few cm (e.g. Lottia digitalis; Frank 1965). In addition, grazers would be expected to cause similar levels of mortality during each of the first few days after settlement since Blanus glandula does not reach a size refuge from limpets until 4 to $8 \mathrm{wk}$ after settlement (Miller \& Carefoot 1989). Bulldozing by limpets and littorines, therefore, does not appear to have been responsible for the elevated levels of first day mortality.

Dislodgement by waves or debris is not believed to be an important cause of first day mortality either, as both the exposed and protected sites showed similar mortality patterns (Fig. 1; and also size-specific mortality, Fig. 3). Delays or complications during metamorphosis, insufficient energy reserves, or even micropredators such as protozoans and nematodes remain as potential causes of high first day mortality.

\section{Conclusion}

Intertidal barnacles can suffer substantial mortality during a brief initial period after settlement. We found no evidence to suggest that enhanced mortality during the first day after settlement was due to interactions with other recruits (density-dependent mortality), desiccation, grazers, or wave action, nor could it be explained by size-dependent changes in vulnerability. First day mortality may be the result of an interaction between 2 or more factors, e.g. energy reserves and ambient temperature. It is possible that selective pressures for traits such as time of settlement relative to the tidal cycle, selection of settlement site, and energy reserves at settlement are most intense during the first 
day in the benthic habitat. For populations that experience high first day mortality, the identification of the causes of this mortality may be the key to establishing the significance of larval and early juvenile traits

Acknowledgements. We thank T. A. Rawlings, K. M. Durante, J. H. Connell, D. Rittschof, and 3 anonymous reviewers for providıng helpful comments on previous versions of the manuscript. Also thanks to the director and staff of the Bamfield Marine Station for providing facilities, equipment and support during this study. Financial support was provided by an NSERC postgraduate scholarship and a Sigurd Tveit Memorial scholarship to L.A.G., a Killiam Postdoctoral Fellowship to P.Y.Q., and an NSERC operating grant to F. S. Chia.

\section{LITERATURE CITED}

Bayne BL (1964) Primary and secondary settlement in Mytilus edulis L. (Mollusca). J Anim Ecol 33:513-523

Boulding EG, Buckland-Nicks J, Van Alstyne KL (1993) Morphological and allozymic variation in Littorina sitkana and related Littorina from the NE Pacific. Velıger 36:58-83

Branch GM (1975) Ecology of Patella species from the Cape Peninsula, South Africa. IV. Desiccation. Mar Biol 32: $179-188$

Caffey HM (1985) Spatial and temporal variation in settlement and recruitment of intertidal barnacles. Ecol Monogr 55:313-332

Chia FS, Burke RD (1978) Echinoderm metamorphosis: fate of larval structures. In: Chia FS, Rice ME (eds) Settlement and metamorphosis of marine invertebrate larvae. Elsevier/North-Holland Blomedical Press, New York, p $219-234$

Connell JH (1961) Effects of competition, predation by Thais lapillus, and other factors on natural populations of the barnacle Balanus balanoides. Ecol Monogr 31:61-104

Connell JH (1972) Community interactions on marine rocky intertidal shores. A Rev Ecol Syst 3:169-192

Connell JH (1985) The consequences of variation in initial settlement vs. post-settlement mortality in rocky intertidal communities. J Exp Mar Biol Ecol 93:11-45

Denley EJ, Underwood AJ (1979) Experiments on factors influencing settlement, survival, and growth of two species of barnacles in New South Wales. J Exp Mar Biol Ecol 36:269-293

Feare CJ (1970) Aspects of the ecology of an exposed shore population of dogwhelks Nucella lapillus (L.). Oecologia 5 : $1-18$

Foster BA (1971) Desiccation as a factor in the intertudal zonation of barnacles. Mar Biol 8:12-29

Frank PW (1965) The biodemography of an intertidal snall population. Ecology 46:831-844

Gaines S, Brown S, Roughgarden J (1985) Spatial variation in larval concentrations as a cause of spatial variation in settlement for the barnacle, Balanus glandula. Oecologia 67 : 267-272

Gosselin LA, Chia FS (1995) Characterizing temperate rocky shores from the perspective of an early juvenile snail: the

This article was submitted to the editor main threats to survival of newly hatched Nucella emarginata. Mar Biol 122:625-635

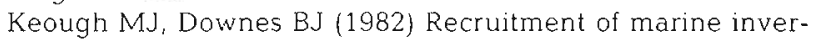
tebrates; the role of active larval choices and early mortality. Oecologia 54:348-352

Kozloff EN (1983) Seashore life of the Northern Pacific coast Douglas \& Mclntyre, Vancouver

Krebs CJ (1985) Ecology. The expermental analysis of distribution and abundance, 3rd edn. Harper \& Row, New York

Miller KM, Carefoot TH (1989) The role of spatial and size refuges in the interaction between juvenile barnacles and grazing limpets. J Exp Mar Biol Ecol 134:157-174

Minchinton TE, Scheibling RE (1993) Variations in sampling procedure and frequency affect estimates of recruitment of barnacles. Mar Ecol Prog Ser 99:83-88

Osman RW, Whitlatch RB (1995) Predation on early ontogenetic life stages and its effect on recruitment into a marine epifaunal community. Mar Ecol Prog Ser 117:111-126

Osman RW, Whitlatch RB, Malatesta RJ (1992) Potential role of micro-predators in determining recrustment into a marine community. Mar Ecol Prog Ser 83:35-43

Petersen JH (1984) Larval settlement behaviour in competing species: Mytilus californianus Conrad and $M$. edulis $L$ J Exp Mar Biol Ecol 82:147-159

Qian PY, Chia FS (1994) In situ measurement of recruitment, mortality, growth, and fecundity of Capitella sp. (Annelida: Polychaeta). Mar Ecol Prog Ser 111:53-62

Qian PY, Liu LL (1990) Recruitment of barnacles into empty adult tests. J Exp Mar Biol Ecol 142:63-74

Ra:mondi PT (1990) Patterns, mechanisms, consequences of variability in settlement and recruitment of an intertidal barnacle. Ecol Monogr 60:283-309

Rowley RJ (1989) Settlement and recruitment of sea urchins (Strongylocentrotus spp.) in a sea-urchin barren ground and a kelp bed: are populations regulated by settlement or post-settlement processes? Mar Biol 100:485-494

Rumrill SS (1990) Natural mortality of marine invertebrate larvae. Ophelia 32:163-198

Sokal RR, Rohlf FJ (1981) Biometry, 2nd edn. WH Freeman and $\mathrm{Co}$, New York

Thorson G (1950) Reproductive and larval ecology of marine bottom invertebrates. Biol Rev 25:1-45

Thorson $G$ (1966) Some factors influencing the recruitment and establishment of benthic marine communities. Neth J Sea Res 3:267-293

Underwood AJ (1979) The ecology of intertidal gastropods. Adv Mar Biol 16:111-210

Vermeij GJ (1972) Intraspecific shore-level size gradients in intertidal molluscs. Ecology 53:693-700

Werner EE, Gilliam JF (1984) The ontogenetic niche and species interactions in size-structured populations. A Rev Ecol Syst 15:393-425

Wethey DS (1984) Spatıal pattern in barnacle settlement: day to day changes durng the settlement season. J Mar Biol Ass UK 64:687-698

Young BL (1991) Spartina axll zones: preferred settlement sites of barnacles. J Exp Mar Bılol Ecol 151:71-82

Yund PO, Cunningham CW, Buss LW (1987) Recruitment and postrecruitment interactions in a colonial hydroid. Ecology 68:971-982

Manuscript first received: June 6, 1995

Revised version accepted: October 24, 1995 